\title{
ANALISIS FAKTOR - FAKTOR YANG MEMPENGARUHI PRODUKSI PADA BUDIDAYA TAMBAK INTENSIF UDANG VANNAMEI DI KECAMATAN PUNDUH PEDADA KABUPATEN PESAWARAN LAMPUNG
}

\author{
Ilham Ramadhani, Elpawati* dan Rizki Adi Puspitasari
}

\begin{abstract}
ABSTRAK
Penelitian ini bertujuan untuk (1) mengetahui faktor-faktor yang mempengaruhi udang Vannamei pada tambak intensif, dan (2) menganalisis respon dari produksi udang Vannamei terhadap faktor-faktor produksi. Penelitian ini dilakukan di Kecamatan Punduh Pedada Pesawaran, Lampung. Data dikumpulkan melalui wawancara, kuesioner dan pengamatan langsung. Regresi linier berganda digunakan untuk menganalisis data. Hasil penelitian menunjukkan bahwa faktor-faktor yang mempengaruhi produksi Vannamei adalah benur, pakan, pabrik air, dan kolam renang yang luas. Elastisitas produksi udang Vannamei di Kecamatan Punduh bersifat inelastis.
\end{abstract}

Kata kunci: produksi, budidaya, udang, vannamei

\begin{abstract}
This study aims to (1) determine the factors that affect Vannamei shrimp in intensive pond, and (2) analyze the responses of Vannamei shrimp production to the factors of production. This research was conducted in the District Punduh Pedada Pesawaran, Lampung regency. Data were collected through interviews, questionnaires and direct observations. Multiple linear regression was employed to analyze the data. The results showed that the factors that influence the production of Vannamei shrimp are shrimp fries, feeds, water mills, and spacious pools. Production elasticity of Vannamei shrimp in the district Punduh are inelastics.
\end{abstract}

Keywords: production, aquaculture, shrimp, vannamei

\section{PENDAHULUAN}

Indonesia merupakan negara kepulauan yang mempunyai potensi besar dalam hal pengembangan industri perikanan baik tujuan ekspor maupun untuk memenuhi kebutuhan dalam negeri. Menurut data dari Kementerian Kelautan dan Perikanan (KKP) tahun 2014, perikanan menempati urutan ketiga sebagai salah satu subsektor dari sektor pertanian yang ikut memberikan pendapatan negara. Hal ini sesuai dengan data Produk Domestik Bruto (PDB) Indonesia pada tahun 2013 yang menjelaskan bahwa sumbagan urutan pertama ditempati oleh subsektor tanaman perkebunan dalam miliar rupiah sebesar Rp. 319.532.60. Kemudian diikuti oleh subsektor tanaman pangan 
yang menempati urutan kedua dengan jumlah sumbangan dalam miliar rupiah sebesar Rp.268.268,20. Urutan ketiga ditempati oleh subsektor perikanan dengan sumbangan dalam miliar sebesar Rp.176.148,30. Dari data diatas dapat diketahui bahwa subsektor perikanan merupakan salah satu sub sektor yang memiliki potensi yang sangat besar.
Komoditi udang merupakan komoditas yang memiliki potensi yang tinggi. Hal ini dikarenakan komoditi udang memiliki peran yang besar dalam peningkatan ekspor sub-sektor perikanan. Selain itu komoditi udang merupakan salah satu komoditi ekspor utama Indonesia di sektor perikanan. Hal ini dapat dilihat pada Tabel 1 dan 2.

Tabel 1. Volume Ekspor Komoditi Perikanan Menurut Komoditi Utama Tahun2009-2013 (Ton)

\begin{tabular}{|r|r|l|r|r|r|l|r|}
\hline Tahun & \multicolumn{7}{|c|}{ Komoditi } \\
\cline { 2 - 8 } & Udang & $\begin{array}{l}\text { Tuna, } \\
\text { Tongkol, } \\
\text { Cakalang }\end{array}$ & Mutiara & $\begin{array}{l}\text { Rumput } \\
\text { Laut }\end{array}$ & Kepiting & $\begin{array}{l}\text { Ikan } \\
\text { Lainnya }\end{array}$ & Lainnya \\
\hline 2009 & 150.989 & 131.550 & 17 & 94.003 & 18673 & 430.513 & 55.668 \\
\hline 2010 & 145.989 & 122.450 & 9 & 123.075 & 21.537 & 622.932 & 68.481 \\
\hline 2011 & 158.062 & 141.774 & 24 & 159.075 & 23.089 & 621.632 & 55.693 \\
\hline 2012 & 162.068 & 201.159 & 336 & 174.011 & 28.212 & 538.723 & 124.605 \\
\hline 2013 & 162.410 & 209.072 & 315 & 183.075 & 34.173 & 519.293 & 149.841 \\
\hline
\end{tabular}

Sumber : Kementerian Kelautan dan Perikanan, 2014

Tabel 2. Nilai Ekspor Komoditi Perikanan Menurut Komoditi Utama Tahun 2009-2013 (US \$ $1.000 .000)$

\begin{tabular}{|r|r|l|r|r|r|r|r|}
\hline Tahun & \multicolumn{7}{|c|}{ Komoditi } \\
\cline { 2 - 8 } & Udang & $\begin{array}{l}\text { Tuna, } \\
\text { Tongkol, } \\
\text { Cakalang }\end{array}$ & Mutiara & $\begin{array}{l}\text { Rumput } \\
\text { Laut }\end{array}$ & Kepiting & $\begin{array}{l}\text { Ikan } \\
\text { Lainnya }\end{array}$ & Lainnya \\
\hline 2009 & 1.007 & 352 & 22 & 87 & 156 & 723 & 115 \\
\hline 2010 & 1.056 & 383 & 31 & 135 & 208 & 898 & 150 \\
\hline 2011 & 1.309 & 498 & 31 & 157 & 262 & 1.100 & 160 \\
\hline 2012 & 1.304 & 749 & 31 & 177 & 329 & 965 & 295 \\
\hline 2013 & 1.684 & 764 & 27 & 209 & 359 & 1.056 & 79 \\
\hline
\end{tabular}

Sumber : Kementerian Kelautan dan Perikanan, 2014

Berdasarkan pada Tabel 1 dan 2. bahwa komoditas udang memiliki sumbangan volume ekspor terbesar ketiga setelah volume ekspor ikan tuna dan rumput laut. Hal ini menunjukkan bahwa komoditas udang memilik peranan penting terhadap ekspor dalam sektor perikanan di Indonesia. Selain itu jumlah volume ekspor udang meningkat setiap tahunnya, hal ini menunjukkan bahwa permintaan akan ekspor udang terus meningkat setiap tahunnya. Begitu pula dengan jumlah nilai ekspor, setiap tahunnya jumlah nilai ekspor udang terusmeningkat. Hal ini membuktikan bahwa komoditas udang merupakan komoditas yang memiliki nilai jual yang bagus di pasar internasional. 
Udang merupakan komoditas perikanan yang memiliki sumbangan volume dan nilai ekspor terbesar bila dibandingkan dengan komoditas lainnya. Salah satu penyumbang terbesar dalam komoditas ekspor udang adalah udang Vannamei. Pada kurun waktu tersebut komoditas udang Vannamei mempunyai tingkat produksi yang paling tinggi diantara udang jenis lain seperti udang windu, udang putih dan udang lainnya.

Tabel 3. Produksi Tambak Udang Indonesia Menurut Varietas Tahun 2009-2013 (ton)

\begin{tabular}{|l|r|r|r|r|r|}
\hline \multirow{2}{*}{ Komoditi } & \multicolumn{5}{|c|}{ Tahun } \\
\cline { 2 - 6 } & 2009 & 2010 & 2011 & 2012 & 2013 \\
\hline $\begin{array}{l}\text { Udang } \\
\text { Vannamei }\end{array}$ & $170.971,00$ & $206.577,00$ & $206.719,00$ & $239.112,00$ & $390.278,00$ \\
\hline $\begin{array}{l}\text { Udang } \\
\text { Windu }\end{array}$ & $124.564,00$ & $125.521,00$ & $154.800,00$ & $116.313,00$ & $171.583,00$ \\
\hline $\begin{array}{l}\text { Udang } \\
\text { lainnya }\end{array}$ & $41.486,00$ & $47.169,00$ & $26.969,00$ & $41.099,00$ & $77.094,00$ \\
\hline Total & $337.021,00$ & $379.267,00$ & $388.488,00$ & $396.524,00$ & $638.955,00$ \\
\hline
\end{tabular}

Sumber : Kementerian Kelautan dan Perikanan (2014)

Tabel 3. menunjukkan bahwa produksi tambak udang di Indonesia mengalami kenaikan di setiap tahunnya. Komoditas udang Vannamei merupakan komoditas yang memiliki produksi terbesar setiap tahunnya. Pada tahun 2013 merupakan tahun produksi komoditas varietas udang Vannamei dengan total 390.278 ton. Sementara hasil terendah adalah varietas udang lainnya sejumlah 77.094 ton. Selain itu komoditas udang Vannamei memiliki tren yang terus meningkat dari tahun ke tahun.

Pada Tabel 3. menunjukkan bahwa produksi tambak udang Vannamei di Indonesia dari 2009 sampai 2013 mengalami peningkatan di setiap tahunnya. Terdapat 15 provinsi yang merupakan sentra produksi udang Vannamei Salah satu provinsi yang merupakan sentra produksi udang Vannamei adalah provinsi Lampung. Provinsi Lampung memproduksi udang Vannamei terbesar dibandingkan dengan
14 Provinsi lainnya. Hal ini ditunjukan dalam Tabel 4.

Produksi udang Vannamei pada tahun 2012 terbesar pada Provinsi Jawa Timur dengan total 45.383 ton sedangkan untuk Provinsi Lampung berada diurutan kedua dibawah Jawa Timur. Tahun 2013 produksi udang Vannamei di Lampung mengalami peningkatan yang cukup besar dengan total 72.051 ton tertinggi pertama diantara 14 Provinsi yang ada di Indonesia mengalahkan Povinsi Jawa Timur yang mana pada tahun 2012 Jawa Timur memperoleh produksi terbesar. Dari data diatas juga menunjukan produksi terendah tahun 2012 pada Provinsi Maluku namun pada tahun 2013 produksi terendah pada Provinsi D.I.Yogyakarta.

Berdasarkan permasalahan di atas dapat disimpulkan bahwa nilai dan Volume ekspor komoditas udang sangatlah besar. Hal ini menuntut produksi udang yang lebih besar. Udang Vannamei merupakan komoditas udang 
yang memiliki potensi besar sebagai penyumbang ekspor komoditas udang. Jika dapat dikelola dengan baik dan tepat budidaya udang Vannamei itu mempunyai prospek baik kedepannya. Terlebih jika mengingat bahwa komoditas udang merupakan komoditas ekspor yang bernilai tinggi. Oleh karena itu penelitian saat ini saya akan meneliti tentang "Analisis Faktor-Faktor yang Mempengaruhi Produksi pada Budidaya Tambak Intensif Udang Vannamei di Kecamatan Punduh Pedada, Kabupaten Pesawaran, Lampung.

Tabel 4. Produksi Budidaya Tambak Udang Vannamei Menurut Provinsi Tahun 2012-2013 (Ton)

\begin{tabular}{|l|r|r|}
\hline \multicolumn{1}{|c|}{ Provinsi } & 2012 & \multicolumn{1}{c|}{2013} \\
\hline Lampung & $40.489,00$ & $72.051,00$ \\
\hline NusaTenggara Barat & $38.525,00$ & $56.960,00$ \\
\hline JawaTimur & $45.383,00$ & $47.150,00$ \\
\hline SumateraSelatan & $32.940,00$ & $40.016,00$ \\
\hline JawaBarat & $29.900,00$ & $61.633,00$ \\
\hline JawaTengah & $3.421,00$ & $13.872,00$ \\
\hline Kalimantan Barat & $6.670,00$ & $39.092,00$ \\
\hline Sulawesi Selatan & $4.393,00$ & $8.542,00$ \\
\hline Sulawesi Tenggara & $12.734,00$ & $18.369,00$ \\
\hline SumateraUtara & $19.414,00$ & $19.791,00$ \\
\hline Gorontalo & 39,00 & 996,00 \\
\hline Maluku & 17,00 & $2.065,00$ \\
\hline Sulawesi Barat & 623,00 & $1.138,00$ \\
\hline Bali & $1.585,00$ & $2.932,00$ \\
\hline D.I. Yogyakarta & 597,00 & 812,00 \\
\hline
\end{tabular}

Sumber : Kementrian Kelautan dan Perikanan (2014)

\section{Rumusan Masalah}

1. Faktor - faktor apa saja yang mempengaruhi produksi udang Vannamei pada budidaya tambak intensif di Kecamatan Punduh Pedada Kabupaten Pesawaran, Lampung?

2. Seberapa besar respon produksi udang Vannamei terhadap faktorfaktor produksi di Kecamatan Punduh Pedada Kabupaten Pesawaran Lampung?

\section{METODE PENELITIAN}

\section{Lokasi dan Waktu penelitian}

Penelitian dan pengumpulan data dilakukan pada Februari 2015 hingga October 2015, bertempat di kecamatan Punduh Pedada, Kabupaten Pesawaran, Lampung.

\section{Jenis dan Sumber Data}

Jenis data yang digunakan dalam penelitian ini berupa data primer dan sekunder, yaitu.

1. Data Primer, yaitu data yang diperoleh dalam bentuk lisan maupun tulisan dari hasil penelitian dalam bentuk:

a. Wawancara (interview), yaitu mengadakan tanya jawab dengan pihak 
yang bersangkutan mengenai masalah yang dibahas

b. Kuesioner, yaitu melalui sejumlah pertanyaan tertulis yang digunakan untuk memperoleh informasi dari responden mengenai hal-hal yang terkait dalam penelitian.

2. Data sekunder, yaitu penelitian pustaka. Penelitian ini dilakukan dengan mencari data-data yang diperlukan yang berhubungan dengan masalah dalam pembahasan skripsi, data yang diperoleh melalui buku-buku dan literatur yang ada hubungnnya dengan objek pembahasan.

\section{Metode Pengumpulan Data}

Metode pengumpulan data dilakukan dengan dua cara, yaitu:

1. Studi Dokumentasi

Dokumentasi dapat berupa catatan pribadi, surat pribadi, buku harian, laporan kerja, notulen rapat, catatan khusus, rekaman kaset, rekaman vidio, foto dan lain sebagainya (Sukandarrumidi, 2002). Metode studi dokumentasi yang dilakukan pada penelitian ini yaitu dengan mengumpulkan buku harian, laporan pekerjaan, foto, catatan pribadi dan literatur.

2. Interview

Interview dikenal pula dengan istilah wawancara. Wawancara adalah suatu proses tanya jawab lisan, di mana dua orang atau lebih berhadapan secara fisik, yang satu dapat melihat muka yang lain dan mendengar dengan telinga sendiri suaranya (Sukandarrumidi, 2002). Interview pada penelitian ini dilakukan untuk mengetahui faktorfaktor yang mempengaruhi produksi udang Vanname di kecamatan Punduh Pedada, kabupaten Pesawaran, Lampung.

\section{Metode Analisis Data}

Berdasarkan data yang dikumpulkan, penelitian ini termasuk ke dalam penelitian kuantitatif. Penelitian kuantitatif adalah penelitian yang menggunakan angka dalam penyajian data dan analisis yang menggunakan uji statistika. Penelitian kuantitatif merupakan penelitian yang dipandu oleh hipotesis tertentu, yang salah satu tujuan dari penelitian yang dilakukan adalah menguji hipotesis yang ditentukan sebelumnya (Saebani, 2008).

Analisis data yang digunakan untuk menjawab tujuan pada penelitian ini adalah deskripsi tabulasi. Data kuantitatif pada data tersebut digunakan sebagai data pendukung. Analisis yang digunakan untuk menjawab adalah analisis regresi linier berganda. Data kuantitatif pada data tersebut digunakan untuk mengetahui faktor-faktor mana saja yang mempengaruhi tingkat produksi pada budidaya tambak udang Vannamei. Alat bantu mengelola data berupa SPSS 18

\section{Uji Asumsi Klasik}

1. Multikoleritas

Ghozali (2005) menjelaskan bahwa uji multikolineritas bertujuan untuk menguji apakah model regresi ditemukan adanya korelasi antar variabel bebas (independent). Model regresi yang baik seharusnya tidak terjadi korelasi diantara variabel independen. Multikolineritas dapat dideteksi dengan melihat nilai tolerance dan variance inflation factor (VIF). Nilai cut off yang umum dipakai untuk menunjukan adanya multikolineritas yaitu nilai tolerance $<0,10$ atau sama dengan nilai VIF $>10$.

2. Heteroskedastisitas

Dalam persamaan regresi berganda perlu juga diuji mengenai sama atau tidaknya varians dari residual dari observasi yang satu dengan yang lain. Jika residualnya mempunyai varians 
yang sama disebut Homoskedastisitas dan jika variansnya tidak sama/berbeda disebut Heteroskedastisitas. Analisis uji asumsi heteroskedastisitas hasil SPSS melalui grafik scatterplot antara $\mathrm{z}$ prediction (ZPRED) yang merupakan variabel bebas (sumbu $\mathrm{X}=\mathrm{Y}$ prediksi) dan nilai residualnya (SRESID) merupakan variabel terikat (sumbu $\mathrm{Y}=\mathrm{Y}$ prediksi - Y rill).

Homoskedastisitas terjadi jika pada scatterplot titik-titik hasil pengolahan data antara ZPRED dan SRESID menyebar dibawah maupun di atas titik origin (angka 0 ) pada sumbu Y dan tidak mempunyai pola yang teratur. Heteroskedastisitas terjadi jika pada scatterplot titik-titiknya mempunyai pola yang teratur baik menyempit, melebar maupun bergelombanggelombang. (Suyoto, 2010).

3. Normalitas

Selain uji asumsi klasik multikolinieritas dan heteroskedestisitas, uji asumsi klasik yang lain adalah uji normalitas, dimana akan menguji data variabel bebas (X) dan data variabel terikat (Y) pada persamaan regresi yang dihasilkan. Persamaan regresi dikatakan baik jika mempunya data variabel bebas dan data variabel terikat berdistribusi mendekati normal atau normal sama sekali. (Suyoto, 2010).

\section{Analisis Regresi Linier Berganda}

Analisis regreso linier berganda pada penelitian ini menggunakan fungsi produksi Cobb-douglas. Analisis regresi linier berganda ini digunakan untuk memprediksi faktor-faktor variabel bebas (benur, pakan, kincir air, dan luas kolam) yang mempengaruhi variabel terikat (produksi udang Vannamei di Kecamatan Punduh Pedada). Untuk memperoleh hasil yang lebih terarah menggunakan bantuan perangkat lunak SPSS 18.
Faktor-faktor yang mempengaruhi produksi udang Vannamei di Kecamatan Punduh Pedada Kabupaten Pesawaran Lampung adalah benur (X1), pakan (X2), kincir air (X3), dan luas kolam (X4). Model dugaanyang dilakukan dalam penelitian ini, dirumuskan sebagai berikut

$\log \mathrm{Y}=\log \mathrm{a}+\mathrm{b} 1 \log \mathrm{X} 1+\mathrm{b} 2 \log \mathrm{X} 2$ $+\mathrm{b} 3 \log \mathrm{X} 3+\mathrm{b} 4 \log \mathrm{X} 4+$ e. $\mathrm{Y}=$ Produksi udang Vannamei di Kecamatan Punduh Pedada

$\mathrm{a}=$ Konstanta

b1 $=$ Koefisien benur b2 $=$ Koefisien

pakan

b3 = Koefisien kincir air

b4 = Koefisien luas kolam

$\mathrm{X} 1=$ Variabel benur

$\mathrm{X} 2=$ Variabel pakan

$\mathrm{X} 3=$ Variabel kincir air

$\mathrm{X} 4=$ Variabel luas kolam

$\mathrm{e}=$ Error

\section{Uji t}

Sugiyono (2008) menjelaskan bahwa uji t pada dasarnya menunjukan seberapa jauh pengaruh suatu variabel penjelas secara individual dalam menerangkan variansi variabel terikat dengan rumus sebegai berikut :

$$
t=\frac{\sqrt[r]{n-2}}{\sqrt{1-r^{2}}}
$$

$\mathrm{t}=\mathrm{t}$ hitung yang selanjutnya dikonsultasikan dengan ttabel

$\mathrm{r}=$ Korelasi parsial yang ditemukan

$\mathrm{n}=$ Jumlah sample

Dasar pengambilan keputusan pengujian :

1. Jika t hitung $>$ ttabel maka $\mathrm{H} 0$ ditolak dan terima $\mathrm{H} 1$

2. Jika t hitung < ttabel maka $\mathrm{H} 0$ diterima dan tolak $\mathrm{H} 1$

Hipotesis yang diuji dalam penelitian ini adalah sebagai berikut 
Hipotesis = Bagaimana pengaruh benur terhadap produksi udang Vannamei di Kecamatan Punduh Pedada?

$\mathrm{H} 0=$ Faktor produksi benur tidak berpengaruh nyata terhadap produksi udang Vannamei di Kecamatan Punduh Pedada.

$\mathrm{H} 1=$ Faktor produksi benur berpengaruh nyata terhadap produksi udang

Vannamei di Kecamatan Punduh Pedada Hipotesis = Bagaimana pengaruh pakan terhadap produksi udang Vannamei di

Kecamatan Punduh Pedada?

$\mathrm{HO} \quad=$ Faktor produksi pakan tidak berpengaruh nyata terhadap produksi udang Vannamei di Kecamatan Punduh Pedada.

H1 = Faktor produksi pakan berpengaruh nyata terhadap produksi udang

Vannamei di Kecamatan Punduh Pedada

Hipotesis = Bagaimana pengaruh kincir air terhadap produksi udang Vannamei di Kecamatan Punduh Pedada?

Ho = Faktor produksi kincir air tidak berpengaruh nyata terhadap produksi udang Vannamei di Kecamatan Punduh Pedada.

H1 = Faktor produksi kincir air berpengaruh nyata terhadap produksi udang Vannamei di Kecamatan Punduh Pedada

Hipotesis = Bagaimana pengaruh luas kolam terhadap produksi udang Vannamei di Kecamatan Punduh Pedada?

$\mathrm{H} 0=$ Faktor produksi luas kolam tidak berpengaruh nyata terhadap produksi udang Vannamei di Kecamatan Punduh Pedada.

$\mathrm{H} 1=$ Faktor produksi luas kolam berpengaruh nyata terhadap produksi udang Vannamei di Kecamatan Punduh Pedada

\section{Uji F}

Ghozali (2005) menjelaskan bahwa uji statistik $\mathrm{F}$ pada dasarnya menunjukkan apakah semua variabel independen atau bebas yang dimasukan dalam model mempunyai pengaruh secara bersama-sama terhadap variabel dependent atau terikat. Uji tersebut dilakukan dengan membandingkan signifikasi Fhitung dengan ketentuan :

Jika Fhitung $<$ Ftabel $\alpha$ 0,05, maka H1 ditolak

Jika Fhitung $>$ Ftabel $\alpha$ 0,05, maka H1 diterima.

Hipotesis yang diuji dalam penelitian ini adalah sebagai berikut:

Hipotesis = Apakah faktor produksi benur, pakan, kincir air, dan luas kolam berpengaruh terhadap produksi udang Vannamei di Kecamatan Punduh Pedada secara bersama-sama?

$\mathrm{HO}=$ Seluruh variabel bebas benur, pakan, kincir air, dan luas kolam tidak secara bersama berpengaruh terhadap produksi udang Vannamei di Kecamatan Punduh Pedada.

$\mathrm{H} 1=$ Seluruh variabel bebas benur, pakan, kincir air, dan luas kolam secara bersama berpengaruh terhadap produksi udang Vannamei di Kecamatan Punduh Pedada.

\section{Koefisien Determinasi}

Menurut Santoso (2010), untuk regresi dengan lebih dari dua variabel independen digunakan adjusted R2 sebagai koefisien determinasinya, dengan acuan yang menjadi ukuran seberapa besar penjelasan adjusted R2 adalah seperti pada Tabel 10. Sugiono (2012) menyatakan bahwa untuk melihat seberapa besar tingkat pengaruh variabel 
independen terhadap variabel dependen secara parsial dengan asumsi faktor faktor lain diluar variabel yang terdapat dalam penelitian dianggap konstan, dapat dilakukan dengan menggunakan uji koefisien determinasi. Secara sistematik, rumus Koefisien Determinasi (Kd) adalah sebagai berikut :

$\mathrm{Kd}=\mathrm{r} 2 \mathrm{x} 100 \%$ Keterangan :

$\mathrm{Kd}=$ Koefisien determinasi

$\mathrm{r} 2=$ Koefisien korelasi yang dikuadratkan

Tabel 10. Pedoman Interpretasi Koefisien Determinasi

\begin{tabular}{|l|l|l|}
\hline No & Interval Koefisien & $\begin{array}{l}\text { Tingkat } \\
\text { Hubungan }\end{array}$ \\
\hline 1. & $0,000-0,0199$ & $\begin{array}{l}\text { Sangat } \\
\text { Lemah }\end{array}$ \\
\hline 2. & $0,200-0,399$ & Lemah \\
\hline 3. & $0,400-0,599$ & Cukup Kuat \\
\hline 4. & $0,600-0,799$ & Kuat \\
\hline 5. & $0,800-1,000$ & Sangat Kuat \\
\hline
\end{tabular}

Sumber : Santoso, 2010

\section{Metode Penentuan Jumlah Sampel Populasi}

Populasi menurut Sugiyono (2013), adalah wilayah generalisasi yang terdiri atas obyek atau subyek yang mempunyai kualitas karakteristik tertentu yang ditetapkan oleh peneliti untuk dipelajari dan kemudian ditarik kesimpulannya.

\section{Sampel}

Metode pengambilan sampel
dilakukan dengan teknik non probability sampling dengan teknik Sampel jenuh. Sofian Effendi dan Tukiran (2012) berpendapat bahwa sampel jenuh adalah metode pengambilan sampel bilamana semua anggota populasi diambil sebagai sampel, beberapa referensi sampel jenuh disebut pula dengan sensus, artinya semua populasi dianggap sebagai sampel.

\section{Definisi Oprasional Variabel}

Adapun definisi oprasional variabel yang terdapat dalam produksi pembesaran udang Vannamei pada budidaya intensif sebagai berikut : 1. Total Produksi (Y) adalah total produksi udang Vannamei per siklus yang telah mengalami pemanenan $(\mathrm{kg})$.

2. Jumlah Benur (X1) adalah jumlah benur udang Vannamei yang ditebar di kolam pembesaran (meter/ekor/siklus).

3. Jumlah Pakan (X2) adalah pakan buatan, jumlah pakan yang terpakai dalam proses pembesaran (kg/siklus).

4. Kincir Air (X3) adalah banyaknya kincir air yang digunakan dalam proses produksi (unit/siklus)

5. Luas Kolam (X4) adalah luas keseluruhan lahan kolam yang digunakan untuk pembesaran udang (meter/siklus).

\section{HASIL DAN PEMBAHASAN}

\section{Analisis Faktor-Faktor Produksi Udang Vannamei}

Hasil produksi tambak pada Kecamatan Punduh Pedada disajikan pada Tabel 13. Dimana hasil produksi tambak yang paling besar terdapat pada perusahaan L sebesar $261.000 \mathrm{~kg}$, sedangkan hasil produksi terkecil pada perusahaan B sebanyak $34.000 \mathrm{~kg}$. Rata-rata hasil produksi udang pada Kecamatan Punduh Pedada sebesar $88.193 \mathrm{~kg}$. Dapat diketahui berapa banyak benur, pakan, kincir air dan luas kolam yang digunakan pada setiap perusahaan yang terdapat pada Kecamatan Punduh Pedada.

Tabel 13. Data Produksi Perusahaan di Kecamatan Punduh Pedada 


\begin{tabular}{|r|r|r|l|l|l|r|}
\hline NO & $\begin{array}{l}\text { PERUS } \\
\text { AHAAN }\end{array}$ & $\begin{array}{l}\text { Y TOTAL } \\
\text { PRODUKSI } \\
\mathrm{kg})\end{array}$ & $\begin{array}{l}\text { X1 } \\
\text { BENUR } \\
(\text { ekor/m }\end{array}$ & $\begin{array}{l}\text { PAKAN } \\
(\mathrm{kg})\end{array}$ & $\begin{array}{l}\text { X3 } \\
\text { KINCIR } \\
\text { AIR } \\
(\mathrm{unit})\end{array}$ & $\begin{array}{l}\text { LUAS } \\
\text { KOLAM } \\
\left(\mathrm{m}^{2}\right)\end{array}$ \\
\hline 1 & $\mathrm{~A}$ & 58.874 & 91 & 104.343 & 128 & 41.650 \\
\hline 2 & $\mathrm{~B}$ & 34.000 & 110 & 63.900 & 120 & 36.500 \\
\hline 3 & $\mathrm{C}$ & 136.981 & 106 & 241.625 & 220 & 99.100 \\
\hline 4 & $\mathrm{D}$ & 70.417 & 105 & 126.182 & 175 & 54.500 \\
\hline 5 & $\mathrm{E}$ & 115.500 & 90 & 231.000 & 246 & 100.000 \\
\hline 6 & $\mathrm{~F}$ & 10.300 & 100 & 19.215 & 23 & 13.100 \\
\hline 7 & $\mathrm{G}$ & 130.500 & 100 & 221.850 & 348 & 87.000 \\
\hline 8 & $\mathrm{H}$ & 36.000 & 75 & 50.300 & 120 & 24.000 \\
\hline 9 & $\mathrm{I}$ & 45.000 & 100 & 76.621 & 112 & 33.000 \\
\hline 10 & $\mathrm{~J}$ & 45.000 & 200 & 73.000 & 70 & 17.500 \\
\hline 11 & $\mathrm{~K}$ & 110.000 & 100 & 211.200 & 275 & 76.000 \\
\hline 12 & $\mathrm{~L}$ & 261.000 & 100 & 108.800 & 160 & 39.000 \\
\hline 13 & $\mathrm{M}$ & 72.240 & 90 & 96.150 & 184 & 45.900 \\
\hline 14 & $\mathrm{~N}$ & 102.211 & 104 & 152.675 & 214 & 71.100 \\
\hline 15 & $\mathrm{O}$ & 94.885 & 102 & 159.200 & 144 & 75.500 \\
\hline & Jumlah & 1.322 .908 & 1.573 & 1.936 .061 & 2539 & 813.850 \\
\hline
\end{tabular}

Sumber : Data Primer (olahan)

\section{Analisis Regresi}

Tabel 14. Hasil Regresi Faktor-Faktor yang Mempengaruhi Produksi Udang di Kecamatan Punduh Pedada

\begin{tabular}{|r|l|r|}
\hline No & \multicolumn{1}{|c|}{ Faktor } & $\begin{array}{c}\text { Koefisien } \\
\text { Regresi }\end{array}$ \\
\hline 1 & Konstanta & 0,42 \\
\hline 2 & Benur(X1) & 0,13 \\
\hline 3 & Pakan (X2) & 0,64 \\
\hline 4 & K.Air (X3) & 0,36 \\
\hline 5 & L.Kolam(X4) & 0,02 \\
\hline
\end{tabular}

Sumber : Data Primer (olahan)

Tabel 14. menyajikan data tentang hasil regresi dari faktor-faktor yang mempengaruhi produksi udang Vanname di Kecamatan Punduh Pedada.

Berdasarkan Tabel 14 diperoleh model fungsi produksi pada penelitian ini adalah sebagai berikut : $\log \mathrm{Y}=0,424+0,133 \quad \log \mathrm{X} 1+0,648$ $\log \mathrm{X}_{2}+0,365 \log \mathrm{X} 3+0,022 \log \mathrm{X} 4$

Persamaan tersebut selanjutnya dikembalikan kebentuk asli sehingga menjadi :

$\mathrm{Y}=\mathrm{e}^{0,424} \mathrm{X} 1^{0,133} \mathrm{X} 2^{0,648} \mathrm{X} 3^{0,365} \mathrm{X} 4$

0,022

$\mathrm{Y}=1,528 \times 1^{0,133} \times 2^{0,648} \times 3^{0,365} \times 4^{0,}$ 022

Keterangan :

$\mathrm{Y}=$ ProduksiUdangVannamei

$\mathrm{X} 1=$ Benur

$\mathrm{X} 2=$ Pakan

$\mathrm{X} 3=$ Kincir Air

$\mathrm{X} 4=$ LuasKolam

1. Uji determinasi $\left(\mathrm{R}^{2}\right)$ 
Uji determinasi $\left(\mathrm{R}^{2}\right)$ digunakan untuk melihat sejauhmana variabelvariabel independen benur, pakan,kincir air, dan luas kolam dapa tmempengaruhi veriabel dependen produksi udang Vannamei. Hasil uji determinasi $\left(\mathrm{R}^{2}\right)$ disajikan pada Tabel 15.

Tabel 15 Hasil Uji Determinasi (R2)

\begin{tabular}{|l|c|l|l|}
\hline Model & $\mathrm{R}$ & $\begin{array}{l}\mathrm{R} \\
\text { Square } \\
\left(\mathrm{R}^{2}\right)\end{array}$ & $\begin{array}{l}\text { Adjusted } \mathrm{R} \\
\text { Square }\left(\mathrm{R}^{2} \mathrm{~d}\right. \\
\text { isesuaikan })\end{array}$ \\
\hline 1 &, 878 &, 771 &, 679 \\
\hline
\end{tabular}

Sumber : Data Primer (olahan)

Koefisien determinasi (R2) menunjukkan besarnya variabel independen terhadap variabel dependen pada sebuah model regresi. Berdasarkan pada Tabel 17 dapat dilihat bahwa nilai dari adjusted R2 adalah sebesar 0,679. Hal ini menunjukan bahwa $67,9 \%$ variabel independen yaitu benur, pakan, kincir air, dan luas kolam dapat menjelaskan variabel dependennya yaitu produksi udang Vannamei di Kecamatan Punduh Pedada. Sedangkan sisanya sebesar $32,1 \%$ dijelaskan oleh variabel lain yang tidak dimasukan dalam model. Nilai 0,679 menunjukan tingkat hubungan antara variabel independen dengan variabel dependen berada pada tingkatan kuat.

2. Uji $\mathrm{F}$

Uji F dilakukan untuk mengetahui apakah seluruh variabel independen (benur, pakan, kincir air, dan luas kolam) secara bersama-sama berpengaruh pada variabel dependen (produksi udang Vannamei). Pengujian ini dilakukan dengan membandingkan Fhitung yang didapatkan dari hasil olahan SPSS 18 dengan Ftabel. Berikut ini adalah Tabel 16 yang menunjukan hasil dari olahan SPSS 18.

Tabel 16 Hasil Uji F Produksi Udang Vannamei di Kecamatan Punduh Pedada

\begin{tabular}{|l|l|r|r|r|r|r|r|}
\hline \multicolumn{2}{|l|}{ Model } & $\begin{array}{l}\text { Sum of } \\
\text { Squares }\end{array}$ & df & $\begin{array}{l}\text { Mean } \\
\text { Square }\end{array}$ & $\begin{array}{l}\text { Fhitun } \\
\mathrm{g}\end{array}$ & Sig. & Ftabel \\
\hline \multirow{2}{*}{1} & Regression & 1,209 & 4 &, 302 & 8,400 &, 003 & 3,48 \\
\cline { 2 - 9 } & Residual &, 360 & 10 &, 036 & & & \\
\cline { 2 - 9 } & Total & 1,569 & 14 & & & & \\
\hline
\end{tabular}

Sumber : Data Primer (olahan)

Berdasarkan Tabel 16 dapat diketahui bahwa nilai Fhitung sebesar 8,400 sedangkan nilai Ftabel sebesar 3,48 dengan signifikansi sebesar 0,003 . Besar nilai Fhitung lebih besar dibandingkan dengan Ftabel yaitu $8,400>3,48$ dan nilai signifikansi lebih kecil dari $\alpha(0,05)$ yaitu $0,003<$ 0,05 . Sehingga dapat diketahui bahwa variabel independen secara bersama sama berpengaruh nyata terhadap variabel dependen atau bisa dikatakan bahwa variabel benur, pakan, kincir air dan luas kolam secara bersamaan berpengaruh terhadap produksi udang Vannamei.

\section{Uji t}

Uji $t$ atau pengujian secara tunggal digunakan untuk melihat apakah masing-masing variabel independent (X) memiliki pengaruh terhadap variabel dependent (Y). dalam penelitian 
ini akan dilihat apakah variabel benur, pakan kincir air, dan luas kolam memiliki pengaruh atau tidak terhadap variabel produksi. Berikut ini adalah Tabel 17 yang memperlihatkan data tentang hasil uji t penelitian ini.

Tabel 17 Hasil Uji t

\begin{tabular}{|l|l|}
\hline faktor-faktor & t hitung \\
\hline Benur $(\mathrm{X} 1)$ & 0,199 \\
\hline Pakan $(\mathrm{X} 2)$ & 1,357 \\
\hline K.Air $(\mathrm{X} 3)$ & 0,687 \\
\hline L.Kolam $(\mathrm{X} 4)$ & 0,105 \\
\hline
\end{tabular}

Sumber:DataPrimer (diolah)

Keterangan : $\quad$ tabel0,25 $=0,692$

\section{Benur}

Faktor pertama yang diduga memiliki pengaruh terhadap produksi udang Vannamai adalah benur. Berdasarkan Tabel 17 dapat diketahui bahwa variabel benur memiliki nilai ttabel sebesar 0,692 dan thitung 0,199 sehingga dapat dilihat bahwa nilai thitung < ttabel yaitu $0,199<0,692$ artinya variabel benur tidak memiliki pengaruh nyata terhadap produksi udang Vannamei di Kecamatan Punduh Pedada pada tingkat kepercayaan $75 \%$.

2. Pakan

Faktor kedua yang diduga memiliki pengaruh terhadap produksi udang Vannamei adalah Pakan. Berdasarkan Tabel 17 variabel pakan dapat diketahui bahwa ttabel sebesar 0,692 dan thitung 1,357 dapat dilihat nilai thitung > ttabel yaitu 1,357>0,692 artinya adalah variabel pakan memiliki pengaruh nyata terhadap produksi udang Vannamei di Kecamatan
Punduh Pedada pada tingkat kepercayaan $75 \%$.

3. Kincir Air

Faktor ketiga yang diduga berpengaruh terhadap produksi udang Vannamei adalah kincir air. Berdasarkan Tabel 17 variabel kincir air dapat diketahui bahwa nilai ttabel sebesar 0,692 dan thitung 0,687 dapat dilihat nilai thitung < ttabel yaitu 0,687 <0,692 artinya variabel kincir air tidak memiliki pengaruh nyata terhadap produksi udang Vannamei di Kecamatan Punduh Pedada pada tingkat kepercayaan $75 \%$.

4. Luas Kolam

Faktor ke empat yang diduga berpengaruh terhadap produksi adalah luas kolam. Berdasarkan Tabel 17 dapat diketahui bahwa nilai ttabel sebesar 0,692 dan thitung 0,105 dapat dilihat nilai thitung $<$ ttabel yaitu $0,105<0,692$ artinya variabel luas kolam tidak memiliki pengaruh nyata terhadap produksi udang Vannamei di Kecamatan Punduh Pedada pada tingkat kepercayaan $75 \%$.

\section{Respon Produksi Udang Vannamei}

Respon produksi udang Vannamei di Kecamatan Punduh Pedada terhadap faktor-faktor yang mempengarui produksi udang Vannamei bisa diukur dengan menggunakan elastisitas produksi. Untuk dapat melihat nilai elastisitas produksi pada penelitian ini dapat dilihat dari nilai koefisien regresi yang didapat dari hasil olahan SPSS 18. Elastisitas produksi mengukur perbandingan relatif antara produksi udang dengan perubahan relatif jumlah faktor produksi. Nilai elastisitas produksi udang Vannamei dapat dilihat dari Tabel 18. 
Tabel 18. Elastisitas Produksi

\begin{tabular}{|l|l|l|}
\hline Variabel & $\begin{array}{l}\text { Nilai Koefisien Regresi / } \\
\text { Elastisitas }\end{array}$ & Interpretasi \\
\hline Benur & 0,133 & Inelastis, tidak respon \\
\hline Pakan & 0,648 & Inelastis, tidak respon \\
\hline Kincir Air & 0,365 & Inelastis, tidak respon \\
\hline LuasKolam & 0,022 & Inelastis, tidak respon \\
\hline
\end{tabular}

Sumber : Data Primer (olahan)

Berdasarkan Tabel 18. Dapat diketahui bahwa keempat variabel tersebut bersifat inelastis dimana nilai elastisitas variabel benur sebesar 0,133 dibawah 1. Nilai elastisitas pakan sebesar 0,648 di bawah 1. Nilai elastisitas kincir air sebesar0,365 di bawah 1. Nilai elastisitas pada luas kolam sebesar 0,022 di bawah 1 .

\section{Benur}

Benur mempunyai nilai elastisitas dibawah satu sebesar 0,133 yang berarti benur bersifat inelastis. Dapat diartikan bahwa produksi udang Vannamei di Kecamatan Punduh Pedada tidak respon terhadap faktor produksi benur. Nilai elastisitas tersebut dapat menunjukan juga daerah produksinya, yaitu pada daerah II (efisien dan rasional) dimana saat penambahan input maka output akan bertambah mesikipun tambahan (produk marjinal) mulai menurun namun produksi total akan tetap naik. Daerah II ini akan mencapai pendapatan maksimum.

\section{Pakan}

Pakan memiliki nilai elastisitas dibawah satu sebesar 0,648 yang berarti pakan bersifat inelastis. Dapat diartikan juga bahwa produksi udang Vannamei di Kecamatan Punduh Pedada tidak respon terhadap faktor pakan. Nilai elastisitastersebut dapat diketahui daerah produksinya, yaitu pada daerah II (efisien dan rasional) dimana saat penambahan input maka output akan bertambah meskipun tambahan (produk marjinal) melai menurun namun produksi total akan tetap daik. Daerah II ini akan mencapai pendapatan yang maksimum.

3. Kincir Air

Kincir air memiliki nilai elastisitas dibawah satu sebesar 0,365 yang berarti kincir air bersifat inelastis. Dapat diartikan juga bahwa produksi udang Vannamei di Kecamatan Punduh Pedada tidak respon terhadap faktor Kincir air. Nilai elastisitas tersebut dapat diketahui daerah produksinya, yaitu pada daerah II (efisien dan rasional) dimana saat penambahan input maka output akan bertambah meskipun tambahan (produk marjinal) melai menurun namun produksi total akan tetap daik. Daerah II ini akan mencapai pendapatan yang maksimum.

\section{Luas kolam}

Luas kolam mempunyai nilial elastisitas dibawah satu sebesar 0,022 yang berarti luas kolam bersifat inelastis. Dapat diartikan bahwa produksi Vannamei di Kecamatan Punduh Pedada tidak respon terhadap faktor luas kolam. Nilai elastisitas tersebut dapat diketahui juga daerah produksinya, yaitu pada daerah II (efisien dan rasional) dimana saat penambahan input maka output akan 
bertambah meskipun tambahan (produk marjinal) melai menurun namun produksi total akan tetap daik. Daerah II ini akan mencapai pendapatan yang maksimum.

\section{KESIMPULAN DAN SARAN}

Berdasarkan hasil penelitian yang telah dilakukan mengenai analisis faktorfaktor yang mempengaruhi produksi udang Vannamei di Kecamatan Punduh Pedada, dapat ditarik suatu kesimpulan sebagai berikut :

1. Berdasarkan analisis model CobbDouglas dapat diketahui bahwa dengan nilai R2 sebesar 0,679 atau $67,9 \%$ maka dapat disimpulkan bahwa keempat faktor produksi yaitu benur, pakan, kincir air, dan luas kolam dapat memberikan informasi yang dibutuhkan untuk memprediksi variansi produksi udang Vannamei di kecamatan Punduh Pedada. Berdasarkan uji $\mathrm{F}$ dengan nilai 8,400 dapat disimpulkan bahwa keempat faktor produksi yaitu benur, pakan, kincir air, dan luas kolam bersama sama mempengaruhi produksi udang Vannamei. Berdasarkan hasil uji t dapat disimpulkan bahwa faktor produksi yang berpengaruh nyata adalah pakan sedangkan ketiga faktor produksi benur, kincir air dan luas kolam tidak berpengaruh nyata pada tingkat kepercayaan $75 \%$.

2. Elastisitas produksi pada tambak di Kecamatan Punduh Pedada bersifat inelastis dimana dari keseluruhan nilai elastisitasnya di bawah satu. Dengan itu maka produksi tidak respon terhadap faktor produksi benur, pakan, kincir air, dan luas kolam.

\section{DAFTAR PUSTAKA}

Amri, K. dan Kanna, I. 2008. Budi Daya Udang Vannamei Secara Intensif, Semi Intensif, dan Tradisional. Gramedia Pustaka Utama. Jakarta

Assuri Sofyan. 2008. Manajemen Produksi dan Oprasi Edisi Revisi 2008.

Penerbit Fakultas Ekonomi Universitas Indonesia. Jakarta.

Badan Pusat Statistik Kabupaten Pesawaran (BPS). 2013. Statistik Daerah Kabupaten Pesawaran 2013. Gedong Tataan (ID) : Badan Pusat Statistik Kabupaten Pesawaran.

Dinas Kelautan dan Perikanan Kalimantan Timur 2015. Budidaya Udang Vannamei (Litopenaeus Vannamei) Pola Tradisional Plus. http://dkp.kaltimprov.go.id/jurnal3-budidaya-udangvannameilitopenaeus-vannameipola-tradisional-plus.html.

Di akses pada tanggal 19februari-2015.

Efendi, S dan Tukiran. 2012. Metode Penelitian Survei. LP3ES. Jakarta.

Gaspers, V. 1996. Ekonomi Manajerial Pembuatan Keputusan Bisnis. PT.Gramedia Pustaka Utama. Jakarta

Ghozali, I. 2005. Aplikasi Analisis Multivariate dengan Program SPSS. BadanPenerbit Universitas Dipenogoro. Semarang 
Haliman, R W dan Adijaya, D. 2005. Udang Vannamei. Penebar Swadaya. Jakarta

Hernanto F. 1995. Ilmu Usahatani. Penebar Swadaya. Jakarta

Kementrian Kelautan dan Perikanan (KKP). 2014. Kelautan dan Perikanan dalamAngka Tahun 2014. Pusat Data Statistik dan informasi KKP. Jakarta

Kristina Y. 2014. Analisis Faktor-Faktor yang Mempengaruhi Produksi dan Pendapatan Budidaya Tambak Udang Vannamei di Kecamatan Pasekan Kabupaten Indramayu. IPB. Bogor

Masyhuri. 2007. Ekonomi Mikro. UIN Malang Press. Malang

Rahardja P. dan Manurung M. 2010. Teori Ekonomi Mikro Suatu Pengantar.Lembaga Penerbit Fakultas Ekonomi Universitas Indonesia. Jakarta.

Saebani B. A. 2008. Metode Penelitian. Pustaka Setia. Bandung

Santoso, Singgih. 2010.Buku Latihan SPSS Statistik Parametik. PT. Elex MediaKomputindo. Jakarta

Soekartawi, 2003. Teori Ekonomi Produksi Dengan Pokok Bahasan AnalisisFungsi Cobb Douglas. PT. Raja Grafindo Persada. Jakarta.
Sugiarto, Herlambang T, Brastoro, Sudjana R, Kelana S. 2000. Ekonomi Mikro : Sebuah Kajian Komprehensif. PT. Gramedia Pustaka Utama. Jakarta.

Sugiyono. 2013. Metodologi Penelitian Kuantitatif Kualitatif dan R\&D. Alfabeta, Bandung.

Sukanadarrumidi. 2006. Metodologi Penelitian: Petunjuk Praktis Untuk Penelitian Pemula. Gajah Mada University Press. Yogyakarta.

Suyoto D. 2010. Uji KHI Kuadrat dan Regresi untuk Penelitian. Graha Ilmu.Yogyakarta.

Syafirah S. 2013. Analisis Faktor-Faktor yang Mempengaruhi Produksi Tandan Buah Segar (TBS) di Perkebunan Inti Kelapa Sawit PT. Permata Hijau Pasaman I Provinisi Sumatra Barat. UIN. Jakarta

Tasman A. dan Aima H. 2013 Ekonomi Manajerial Edisi Revisi. Rajawali Pers.Jakarta.

Trenggonowati. 2011. Teori Ekonomi Mikro Edisi Dua. BPFE Yogyakarta

* Alamat Korespondensi: elpawati@gmail.com 
Jurnal Agribisnis, Vol. 12, No. 1, Juni 2018, [61 - 74]

ISSN : 1979-0058 